\title{
9. HEAVY MINERALOGY AND PROVENANCE OF VOLCANICLASTIC TURBIDITES OF SITE 386
}

\author{
Jon S. Galehouse, San Francisco State University, San Francisco, California
}

\section{INTRODUCTION}

Upper Eocene to middle/upper Oligocene volcaniclastic turbidites were cored at Site 386 on the central Bermuda Rise, about $140 \mathrm{~km}$ south-southeast of Bermuda. The turbidites occur throughout an approximately 170 -meter interval and contain significant amounts of heavy minerals and zeolites. This paper relates Eocene and Oligocene igneous activity and tectonism on Bermuda to the emplacement of the volcaniclastic turbidites by comparing the detailed heavy mineralogy of the turbidites to the petrography of igneous units on Bermuda.

The volcaniclastic turbidites constitute Subunit 3B of the stratigraphic section at Site 386 (see Site 386 Report,this volume). The volcaniclastic turbidites have an uncored lower contact in the 9.5-meter interval between Cores 13 and 14. The upper contact with calcareous turbidites is gradational over about a 7-meter interval from Core 4, Section 5 to Core 5, Section 2.

\section{METHODS}

Samples were taken from 14 intervals in 13 different turbidite layers. Smear slides were made and examined to determine the general mineralogic composition. The samples were then separated by sieving into 44-63 and 63-500 $\mu \mathrm{m}$ size fractions. Heavy minerals were separated from light minerals in both size fractions using bromoform (specific gravity 2.89) and the common gravity separation method (Carver, 1971). The heavy minerals in both size fractions were then mounted on separate slides. In four of the fourteen intervals, only the 44 to $63 \mu \mathrm{m}$ fraction contained enough heavy minerals to make a statistically valid count. In two instances, counts were made of both size fractions from the same sample. The results indicate that the composition of the heavy mineral fraction is not significantly related to grain size.

Counts were made using the ribbon method (Galehouse, 1971), and 300 grains were identified on each slide. Mica and altered and opaque grains were not included in the count of 300 , but their abundance was tallied separately (see Table 1).

\section{RESULTS}

The non-opaque heavy mineral assemblage of the volcaniclastic turbidites at Site 386 is overwhelmingly dominated by clinopyroxene (see Table 1). Most of the clinopyroxene grains are fresh and easily identified. Some, however, are considerably etched.

The upper tenth and the lower nine-tenths of the interval show some minor differences in mineralogy. The mineral assemblage of the uppermost portion consists of about 81 percent clinopyroxene, 10 percent apatite, and 2 or 3 percent each of hornblende, epidote group, and garnet. That of the lower portion consists of about 91 percent clinopyroxene, and 1 to 3 percent each of apatite, epidote group, orthopyroxene, and hornblende. Although not detected in this study, chrome spinel has been identified in other samples from the upper tenth of this interval (see Murdmaa, this volume).

Opaque grains are about equally common in both the upper and lower portions. They are slightly more abundant on the average than the sum of all the nonmicaceous grains identified. Opaque grains have not been identified systematically throughout the interval. However, some of the heavy fractions were subjected to X-ray analysis, and some were checked in reflected light and with a magnet. It appears the opaques in the volcaniclastic turbidites are dominantly magnetite.

Altered grains are about one-fourth as abundant overall as the sum of the non-micaceous grains identified. Slides of the 44-63 $\mu \mathrm{m}$ fraction contain an average of about 4 times as many altered grains as slides of the 63-500 $\mu \mathrm{m}$ fraction. In addition, the lower 40 percent of the interval contains only about a sixth as many altered grains as the upper portion.

Mica is about as abundant as apatite in the turbidites. Most of the mica appears to be biotite, but a few of the lighter colored grains may be phlogopite. Rare muscovite grains were also noted.

\section{DISCUSSION}

The volcaniclastic turbidites at Site 386 on the central Bermuda Rise appear to have been derived from the vicinity of the island of Bermuda. In 1972, an 800-meter-deep borehole was drilled on Bermuda under the direction of scientists at Dalhousie University. Several reports have been presented concerning various aspects and interpretations of the drilling results that are of particular importance to this study including age dating (Reynolds and Aumento, 1974) and petrology and geochemistry (Aumento and Gunn, in press).

Although the data are somewhat scattered and some of the numbers are rejected for one reason or another, Reynolds and Aumento (1974) conclude that much of 


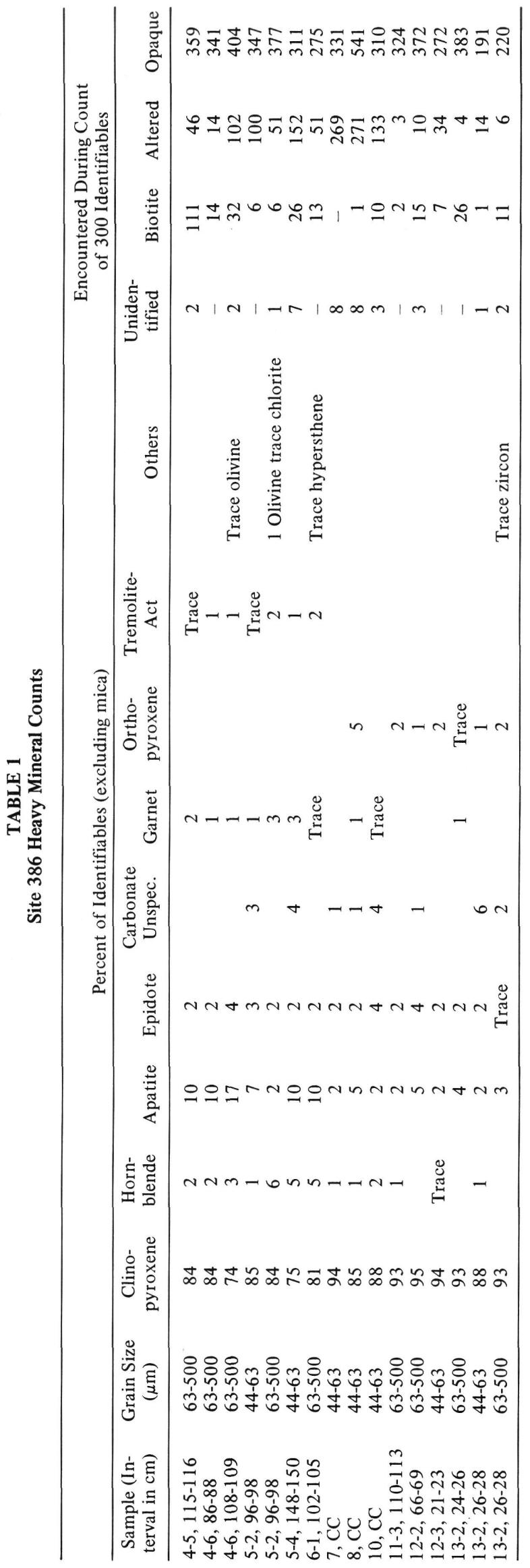

the Bermuda Seamount was formed about 33 million years ago in Oligocene time. This suggests that renewed igneous activity developed in the Bermuda area considerably after formation of the surrounding sea floor. Aumento and Gunn (in press) state that about two-thirds by volume of the igneous units cored are pillow lavas that are low potassium oceanic tholeiites and were probably emplaced when Bermuda was near the Mid-Atlantic Ridge about 90 to 110 million years ago. Most of these flows have been altered to spilites. About one-third of the igneous units cored are sheeted basic dikes that intruded the spilites about 33 million years ago. Aumento and Gunn (in press) report that clinopyroxene is by far the most abundant and least altered mineral in the dikes, as both phenocrysts and groundmass. The other common phenocrysts are mica and titaniferous magnetite.

The heavy mineralogy at Site 386 is very similar to that in the dikes cored on Bermuda. In both cases, clinopyroxene dominates. The only other heavy minerals common in the Bermuda cores are mica and magnetite which are also conspicuous in the volcaniclastic turbidites. The mica on Bermuda was identified by microprobe analysis as phlogopite, whereas that in the turbidites was identified optically as biotite. Of the other heavy minerals present in small amounts in the turbidites, the garnet and epidote may have been formed by alteration of the igneous rocks of Bermuda. The apatite may be authigenic.

Etching of some of the clinopyroxene grains is consistent with a suggested emergence of Bermuda during Eocene/Oligocene time.

The initiation of the turbidity currents which emplaced the volcaniclastic turbidites may correspond with renewed igneous activity on Bermuda. This suggests that renewed activity began about 40 million years ago, in late Eocene time. This is somewhat earlier than the 33 million year radiometric age on the Bermuda dikes (Reynolds and Aumento, 1974).

Emplacement of the volcaniclastic turbidites ceased during middle/late Oligocene time. Thus, Bermuda acted as a major sediment source for about 15 million years.

Data other than the heavy-mineral studies reported here also are indicative that Bermuda was the source area for the volcaniclastic turbidites at Site 386. Because of their relevance to this study, they bear summarizing:

1) The seismic reflector associated with the top of the volcaniclastic turbidites can be traced in seismic profiles toward Bermuda where it merges with the acoustically opaque archipelagic apron of the Bermuda pedestal. (Tucholke, this volume).

2) Shallow-water detritus associated with the turbidites indicates a source area that was near or partially above sea level.

3) The high percentage of zeolites (averaging between 4 and 5 percent of the bulk composition) and the low percentage of quartz (averaging less than 1 percent) in the turbidites are both consistent with an oceanic volcanic source. 


\section{SUMMARY}

Eocene and Oligocene volcaniclastic turbidites cored at Site 386 on the central Bermuda Rise were derived from dikes comprising much of the Bermuda pedestal. The emplacement of the turbidites corresponds to renewed igneous activity on Bermuda, some 50 to 70 million years after formation of the surrounding sea floor.

\section{ACKNOWLEDGMENTS}

I would like to thank F. Scantena and M. Lewis of San Francisco State University for slide preparation and G. Müller and P. Rothe of the University of Heidelberg for providing office and lab facilities during my sabbatical leave when this and related research was largely accomplished.

\section{REFERENCES}

Aumento, F. and Gunn, B., in press. Deep Drill-1972, petrology and geochemistry of the Bermuda Seamount: $J$. Petrol.

Carver, R. E., 1971. Heavy-mineral separation. In Carver, R. E. (Ed.), Procedures in sedimentary petrology: New York (Wiley-Interscience), p. 427-452.

Galehouse, J. S., 1971. Point counting. In Carver, R. E. (Ed.), Procedures in sedimentary petrology: New York (Wiley-Interscience), p. 385-407.

Reynolds, P. H. and Aumento, F., 1974. Deep Drill-1972, potassium-argon dating of the Bermuda drill core: Canadian J. Earth Sci., v. 11, p. 1269-1273. 